DOI: 10.2478/rae-2020-0010 Review of Artistic Education no. 192020 81-84

\title{
10. COMPARATIVE INTERPRETATIVE ANALYSIS OF DAVID MANCINI'S WORK SUITE FOR SOLO DRUMSET AND PERCUSSION ENSEMBLE
}

\author{
Constantin Stavrat ${ }^{118}$
}

\begin{abstract}
The endless possibilities of expression that jazz has developed over the last hundreds of years could not only influence the composers, but also the performers who dedicated themselves to the fascinating and complex field of percussion. One of the percussion players who has been influenced by this genre is David Mancini, whose conposition I chose for comparative analysis - Suite for solo drum and percussion ensemble in the interpretation of two percussion ensembles Vibraslap and Guiro, whose activity was perpetuated due to enthusiasm and the professionalism of the two mentors of the respective groups, professors Marian Vaida and Bedo Gabor, both perfected within the percussion class of the Conservatory of Music "George Enescu" in Iasi Romania, founded and led for more than half a century by the renowned professor Florian Simion. Two totally different interpretations of David Mancini's work - Suite for solo drums and percussion ensemble, each with a few moments of success, but also with the need to perfect many elements of technique and interpretive design.
\end{abstract}

Key words: percussion ensemble, jazz, comparative analysis

\section{Introduction}

The endless possibilities of expression that jazz has developed over the last hundred years could not only influence the composers, but also the performers who have dedicated themselves to the fascinating and complex field of percussion. It is the field which, in turn, has greatly diversified and perfected its arsenal of tools, thus offering unique, extremely varied possibilities of expression for creators and performers alike.

\section{Discussions}

Born on April 22, 1952 David Mancini is a graduate of the Eastman School of Music, where he was awarded the Performer's Certificate. Mancini's versatility as a drummer and percussionist has garnered him appearances with such diverse artists as Chuck Mangione, Eddie Daniels, Urbie Green, Marvin Stamm, Jeff Tyzik, Don Menza, Toshiko Akiyoshi, Rosemary Clooney, Diahann Carroll, Maureen McGovern, Joe Williams, Tony Bennett, Johnny Mathis and Bop Hope. From 1971-1981 Dave was a member of the percussion section of the Rochester (NY) Philharmonic Orchestra. In the early 1980's he spent a year and a half performing, touring and recording with Maynard Ferguson. In 2003, Dave was invited to be the drummer for the Maynard Ferguson Alumni Band, which performed in Boston to celebrate Maynard's 75th birthday.

As the touring drummer for Doc Severinsen and conductor Jeff Tyzik, Dave

\footnotetext{
${ }^{118}$ Lecturer PhD., "George Enescu” National University of Arts from Iaşi, Romania, email: stavrat@gmail.com
} 
Mancini has performed with the majority of symphony orchestras in the United States and Canada including: The Boston Pops, Chicago Symphony, Pittsburgh Symphony, Toronto Symphony, Minnesota Orchestra, Detroit Symphony, New York pops, Vancouver Symphony, Dallas Symphony, and the Milwaukee Symphony. Dave is in great demand as an artist/clinician for the Avedis Zildjian Cymbal Company, Yamaha Drums, and Vic Firth, Inc., presenting hands-on workshops and master classes at numerous colleges and public schools around the country each year.

I had the opportunity, by obtaining two recordings - video and audio, to meet two school percussion ensembles - Vibraslap and Guiro, whose activity was perpetuated over time due to the enthusiasm and professionalism of the two mentors of the respective groups, Professor Marian Vaida. and Bedő Gábor, both perfected within the percussion class of the Conservatory of Music "George Enescu" in Iasi Romania, founded and led for more than half a century by the renowned professor Florian Simion.

The Vibraslap percussion ensemble was founded in 1984 at Jugendmusikschule Heidenheim, Germany, by percussionist and professor Marian Vaida ${ }^{119}$, graduate of the "George Enescu" Conservatory of Music in Iaşi, in the percussion class of the university professor Dr. Florian Simion. With a tradition of three decades, this school ensemble, whose members, naturally, change every year, has been affirmed and is still affirmed for three decades, in numerous concerts in Germany, Hungary, France and Romania, the proffesor Marian Vaida permanently maintaining the artistic breath in the musical life of the ensemble.

The Guiro percussion ensemble was founded in 1987 at the Franz Liszt School of Music (since 1992, the school is named after Peter King Konig) in Szeged, Hungary, by Professor Bedő Gábor ${ }^{120}$, a graduate of the "George Enescu" Conservatory of Music in Iasi. , also in the precussion class of university professor Dr. Florian Simion. Over the years, the ensemble has changed its componence, but the joy of making music has remained the same, many of the ensemble members subsequently activating in other percussion ensembles. The repertoire of the Guiro ensemble is very diverse and includes both original creations of

\footnotetext{
${ }^{119}$ Founder and director of the Vibraslap percussion ensemble, Marian Vaida is a percussion teacher, at the Heidenheim Music Schools (1983), Gerstetten (1985) and Steinheim (1997). Between 1971 and 1982 he was an instrumentalist (solo timpanist, and percussionist) at the State Philharmonic in Iasi and Arad and percussion teacher at the Music High Schools in Iasi and Arad. In 1982, he received the first prize at the National Chamber Music Competition. Attended several training courses and seminars, including for group lessons. He is a member of Cappella Aquileia, Wurttemberg Kammerph Hedenheim and also organizer of various projects, such as "Classic $\&$ Rock" and "Night of Music".

${ }^{120}$ The Guiro ensemble founded by Professor Gabor Bedo at the Franz Liszt School of Music in Szeged participates in concerts held in Szeged or in neighboring cities, as well as in percussion competitions, such as the National Competition at the University of Szeged Ki -Mit - Tud (1996, Laszlo Kurti finalists), the Országos Szóló és Duó contest (Pocskai Zsolt I, won the first prize in the category of the born in 2003), at the Ceglédi gala (in 2004) the drummer Gábor Dörnyei "Aranydobverö" participated. He has also given concerts abroad: Austria, Germany and Romania, charity concerts (for the victims of 1999, for the benefit of the Szeged Children's Clinic in 2000, for the renovation of the organ of the Roman Catholic church in Petöfi in 2004, to help the sick children in 2007, etc.)
} 
Hungarian and foreign composers, as well as transcripts of works of popularity, as well as traditional pieces from African and South American music. Between the Vibraslap percussion ensemble and the Guiro percussion ensemble there is a close and beautiful collaboration, materialized through series of concerts performed together. From the recorded repertoire of the two ensembles I was able to make a comparison of how to perform one of the major works in the international repertoire - Suite for solo Drumset and percussion ensemble by

\section{David Mancini.}

The ensemble Vibraslap approached in the interpretation of the Suite a moderate Tempo, the soloist beginning with a own play of the tempo, different from the one written in the original score, he adding a much more varied rhythmic line to the one indicated by the composer, and throughout the song using the technique called paradidle. It is also observed that the other performers respect the agogics and dynamics mentioned by the author in the score. At the end of the first theme, the soloist performs, with a high level of percussion technique, a new solo on the drum set. Thus, he enriches the content of the piece with his own improvisation, in the score being not indicated such a drum solo. In my opinion, in this interpretation the solo is, however, a bit long in duration. It is necessary, therefore, the correct sizing of such solos in time, in order not to lead to a certain monotony.

In the second section, the ensemble performs a common crescendo, thus respecting the composer's instructions. It is noted, however, that the solos of the melodic instruments are covered by the drum set. On tom-toms, for example, it is forcibly executed, covering the main theme on the vibraphone. Therefore, in the flow of the interpretation, it is desirable for the rhythmic section to play in the $m p$ dynamics, in order to be able to highlight the melodic line. At the beginning of the third section, the soloist shows his technical possibilities again, interpreting a samba rhythm solo with a high technical difficulty. However, this time, the main theme, melodic, from the marimba and vibraphone is covered by the membranophone instruments. Therefore, it would have been desirable for the players of the membranophone instruments to be guided to realize that they only provide rhythmic support in the melodic display.

\section{Conclusions}

As for the Guiro ensemble, the tempo approached is close to that indicated. The main theme is also duplicated at xylorimba. However, the drummer soloist does not have a very high performing technique. He does, however, respect the rhythmic indications in the score. Due to the lack of timpani, the timpani player plays on a set of 4 tom-toms tuned approximately in the tone of the work. At the same time, it is noted that due to the average level of training of the percussion players, the work does not run in a constant tempo. The solo on the drum set is not sufficiently elaborated, it is modestly realized as a technical difficulty. In the second section the percussionist uses another instrument instead of the one 
indicated by the composer, namely the cow-bell. Regarding the third section, it can be observed that the absence of the timpani is replaced by the insertion in the componence of the ensemble of a bass guitar, which replaces the notes with a height determined in the lower register written on timpani.

\section{References}

1. Bughici Dumitru - Dictionary of musical terms, Bucharest 1978

2. Gâscă Nicolae - Treatise on the theory of instruments, vol. 2, Bucharest 1998

3. Simion Aurelia -"Să lași loc de bună ziua ", portrait of musician and teacher Florian Simion, 2nd edition, Artes Publishing House, Iași 2017

\section{Webography}

4. https://youtu.be/cSRnOxnMC1g

5.https://www.mostlymarimba.com/composers/composersko/695.html?itemid=27

6. http://www.perctek.com/index.php?title=Mancini,_David 